\title{
Simultaneous extraction of oil and protein from perilla seed by three-phase partitioning and their application in serum
}

\author{
Punyawatt Pintathong ${ }^{1,2}$, Phanuphong Chaiwut ${ }^{1,2^{*}}$, Natthawut Thitipramote ${ }^{1,2}$, \\ Nont Thitilertdecha ${ }^{1,2}$, Witayapan Nantitanont ${ }^{1,2}$, Sarita Sangthong ${ }^{1,2}$ and \\ Ninnapat Tiensri ${ }^{1}$ \\ ${ }^{1}$ School of Cosmetic Sciences, Mae FahLuang University, Chiang Rai, Thailand, 57100 \\ ${ }^{2}$ Green Cosmetic Technology Research Group, Mae FahLuang University, Chiang Rai, Thailand, 57100 \\ *E-mail: phanuphong@mfu.ac.th
}

\begin{abstract}
Perilla seeds contain high amount of oil and protein. This study was aimed to simultaneously extract oil and protein from perilla seed by using three-phase partitioning method (TPP). The extraction conditions were optimized by varying the ratio of crude extract to $t$-butanol of 1:2, 1:1 and 2:1 (v/v) and ammonium sulfate concentration of 20, 30 and $40 \%$ $(\mathrm{w} / \mathrm{v})$. The crude extract to $t$-butanol at $1: 2$ and $30 \%(\mathrm{w} / \mathrm{v})$ ammonium sulfate resulted in the highest recovery of perilla oil $(35.13 \pm 2.67 \%)$ and protein $(13.18 \pm 0.65 \%)$. This provided 14 folds of time saving when compared to conventional method of oil and protein extraction separately. The obtained perilla protein and oil extracts were included in the facial serum formulation. Stability and satisfaction of the serum formulation were tested compared to its base formula. The perilla facial serum showed its good stability after accelerated conditions of centrifugation and heating-cooling for 4 cycles. The phase separation and $\mathrm{pH}$ changing was not observed. The viscosity and the color were slightly affected by the accelerated condition. The satisfaction test including moisturizing sensory of the serum was evaluated by 20 volunteers. The product was satisfied with average score 5.47 of the maximum 6 level. This study emphasized the valuable perilla seed protein and oil could be extracted by single step of TPP and feasibly included into moisturizing facial serum product.
\end{abstract}

Keywords: perilla seed, protein, oil, serum, three-phase partitioning (TPP)

\section{Introduction}

Perilla frutescence (perilla) is an aromatic herb originated in some Asian countries including Thailand, Korea, India and China and now throughout world-wide. The perilla stalks, leaves and seeds have been repoted as a rich source of omega- 3 polyunsaturated fatty acids (PUFAs), specifically alpha-linolenic acid (ALA). It also contains omega- 6 and omega-9 fatty acids which are the essential for health (Mohammad \& Atul, 2010). The seeds of perilla are a good source of oleic acid, stearic acid and palmitic acid (Chang et al., 2009; Peiretti et al., 2011). Earlier studies have shown that perilla seed is a potential source of fat $(51.7 \%)$ and protein (17.0\%) (Longvah \& Deosthale, 1991). The lipids consisted of 91.2-93.9\% neutral lipids, 3.9-5.8 \% glycolipids and 2.0-3.0\% phospholipids (Shin \& Kim, 1994). The contents of tocopherol were $734 \mathrm{mg} / \mathrm{kg}$ in perillain which $\mathrm{\gamma}$-tocopherolis dominating isomer contributing $94.3 \%$ in perilla to the total amount of tocopherols (Scapin et al., 2017). The leaves and seeds 
of perilla have been found to have many other components such as beta-sitosterol and ampesterol (Honda et al., 1986), flavonoids such as apigenin, luteolin, chrysoeriol, quercetin, catechin, and phenolic acids such as caffeic acid and rosmarinic acid (Lee et al., 2013; Mohammad \& Atul, 2010). Perilla possesses various bioactivities, such as antioxidant (J ung et al., 2011), anti- inflammatory (Ueda et al., 2002), anti-allergic (Makino et al., 2013; Takano et al., 2004) and anticancer (Narisawa et al., 1994). In the North of Thailand, the perilla seeds are widely consumed as flavoring and nutritional sources. Perilla oil is widely used as dressing or cooking (Shin \& Kim, 1994). Volatile oils of the plant are also used in aromatherapy and perfume (Povilaitytee \& Venskutonis, 2000). Moreover, the perilla extract from the leaves, seeds and oils has also been used in nutritional and cosmetic formulations (Mohammad \& Atul, 2010; Terranova et al., 2006). However, the perilla protein which is mostly readily digestible (Oita et al., 2008) has not been documented for industrial application.

Several methods have been reported for the extraction and purification of protein, such as alcohol and salt precipitation, ion exchange chromatography, membrane separation (Azarkan et al., 2003), and aqueous two-phase extraction (Tan et al., 2015). Although these methods are effective, there are many disadvantages such as high cost and time demands, or difficult to scale-up (Tan et al., 2015). Various methods for extracting the oil from the seeds have been reported and conventional method of solvent extraction is the most widely used technique, due to its high efficiency in oil recovery. However, the major disadvantage in using solvent extraction technique is its high energy input and toxicity from large amount of solvent used (Shivani et al., 2011).

An effective technique for the separation and purification of enzymes, proteins and edible oils called three-phase partitioning (TPP) has been introduced (Chaiwut et al., 2010; Rawdkuen et al., 2010; Gagaoua et al., 2014). This method uses ammonium sulfate to achieve a saturation and precipitation of protein and $t$-butanol was added to make three distinct phases and the purified biomolecules was found in the interphase (Chaiwut et al., 2010). It is simple, less time consuming, and maintains the nature of the protein (Rachana \& Lyju, 2014). Purification of aloe polysaccharide (APS) and protein resulting in highly effective APS extract (Tan et al., 2015) was an example of using the TPP for single step extraction of bioactive compounds. Extraction of protein and oil from the plant source by using one step method has not been reported. Therefore, the aims of the study were to simultaneously extract the protein and oil from perilla seed by using the TPP method and develop facial serum containing perilla protein and oil.

\section{Materials and methods \\ Plant sample and chemical reagent}

Dry perilla seeds were collected from Hangdong district, Chiang Mai province, Thailand during January to Febuary 2016. The seeds were air dried for 3 days. Tert-butanol (2-methyl-2propanol) and ammonium sulfate $\left(\left(\mathrm{NH}_{4}\right)_{2} \mathrm{SO}_{4}\right)$ were obtained from Merck (Darmstadt, Germany). Coomassie Brilliant Blue G-250 was purchased from Sigma Chemical (St. Louis, MO, USA) and 95\% ethanol was supplied from Quality Reagent Chemical. Bovine serum albumin (BSA) was obtained from Fluka (Buchs, Switzerland). Alpha tocopheryl acetate (Vitamin E acetate) was supplied from Eisal Co. Cosmetic raw materials were purchased from suppliers: Godrej Industries, Chemico Inter Corparation, Qingdao Fuso Refining \& Processing, Innospec, Nam Siang Trading, and Lubrizol. 


\section{Preparation of crude extract from perilla seeds}

The seeds of perilla were dried in a tray-dryer at $55^{\circ} \mathrm{C}$ until the weight was constant. The seeds were ground in a blender and then homogenized with water at a ratio of 1:2 w/v. Then the homogenate was filtered through a Whatman filter paper No.1. The filtrate was centrifuged at $5000 \mathrm{~g}$ at $4^{\circ} \mathrm{C}$ for $20 \mathrm{~min}$. The obtained supernatant was referred to the "crude extract" and stored at $-20^{\circ} \mathrm{C}$ until used.

\section{Extraction of perilla protein and oil by three-phase partitioning (TPP)}

The TPP composed of crude extract, $t$-butanol and $\left(\mathrm{NH}_{4}\right)_{2} \mathrm{SO}_{4}$. The mixture was partitioned by orbital shaking at $150 \mathrm{rpm}$ for $10 \mathrm{~min}$ and centrifuged at $5000 \times g$ at $4^{\circ} \mathrm{C}$ for 20 min. The top phase ( $t$-butanol) were collected and evaporated by rotary evaporater for oil determination and the interphase was collected for protein quantification. The partitioning compositions of the sample per $t$-butanol ratio and the concentration of $\left(\mathrm{NH}_{4}\right)_{2} \mathrm{SO}_{4}$ were varied for studying their effect on simultaneous extraction of protein and oil from perilla seed. The ratio of crude extract to $t$-butanol was varied as $1: 2,1: 1$ and $2: 1(\mathrm{v} / \mathrm{v})$ with a constant $30 \%$ $\mathrm{w} / \mathrm{v}\left(\mathrm{NH}_{4}\right)_{2} \mathrm{SO}_{4}$ and the extraction was carried out as mention above. The ratio of crude extract to $t$-butanol which provided the highest recovery was chosen for study of the effect of $\left(\mathrm{NH}_{4}\right)_{2} \mathrm{SO}_{4}$ concentration on protein and oil partitioning. The $\left(\mathrm{NH}_{4}\right)_{2} \mathrm{SO}_{4}$ concentration was varied at 20,30 and $40 \%(w / v)$.

\section{Determination of protein and oil}

The concentration of protein in the interphase was measured by Bradford method (Bradford, 1976) using bovine serum albumin (BSA) as protein standard. Protein recovery (\%) was calculated from protein amount of interphase compared to initial protein amount in crude extract. Top phase from the TPP was subjected to remove $t$-butanol by using rotary evaporator. Oil recovery (\%) was calculated from oil weight of the top phase compared to initial weight of perilla seeds.

\section{Analysis of fatty acid compositions}

Fatty acid compositions of perilla oil were analyzed by using GC-MS. The fatty acid methyl esters (FAMEs) of perrila seed oil was prepared by saponification of 3 grams oil with 0.9 $\mathrm{M} \mathrm{H}_{2} \mathrm{SO}_{4}$ in methanol ( $3 \mathrm{~mL}$ ) and $1 \mathrm{~mL}$ of toluene (Siriamornpun et al., 2006). The mixture was refluxed for 2 hours at $75-80^{\circ} \mathrm{C}$ and the solvent was removed by rotary evaporator at $40^{\circ} \mathrm{C}$. Recovered FAMEs sample was adjusted to $\mathrm{pH}$ 6. The GC-MS analysis was carried out as the system composed of $0.25 \mathrm{~mm} \times 30 \mathrm{~mm} \times 0.25 \mu \mathrm{m}$ capillary column (Agilent $190915-43 \mathrm{HP}-5 \mathrm{MS}$ ) at $250^{\circ} \mathrm{C}$ using helium as a carrier gas with $1.0 \mathrm{~mL} / \mathrm{min}$. The injector and detector temperature were set at $220^{\circ} \mathrm{C}$. The FAMEs was detected at 20-250 Da and identified by NI ST08 database.

\section{Development of serum containing perilla protein and oil}

Oil/water facial moisturizing serum was developed by using ingredient listed on Table 1. The ingredients of the oil phase (phase A) were mixed at room temperature. In the same time, the aqueous part was mixed and then the oil phase was added to the water phase under mechanical stirring. The emulsion was continuously stirred and the $\mathrm{pH}$ was adjusted by using citric acid solution of part C. The proper texture of base formula was obtained after alteration amounts the ingredients. Stability of the base serum was checked by using centrifugation and heating-cooling accerelation test for 4 cycles. The formula providing the highest stability ( $\mathrm{pH}$, color and viscosity) and organoleptical characteristics (aspect, color and odor) was selected for 
the base serum. In case of the serum containing oil and perilla protein, the perilla oil was added to replace jojoba oil and perilla protein solution was part $D$ as described in the Table 1 .

\section{Stability test}

The base serum and the serum containing perilla oil and protein ( $1.00 \mathrm{~g}$ ) were centrifuged at $6000 \mathrm{rpm}$ for $20 \mathrm{~min}$. None of phase separation was observed. Then the base serum and the products were tested under accelerated condition of heating and cooling of $50^{\circ} \mathrm{C}$ and $4^{\circ} \mathrm{C}$ for 4 cycles. Before and after accerelation test, $\mathrm{pH}$, viscosity and color of the products were measured. The $\mathrm{pH}$ of the serums was measured by using $\mathrm{pH}$ meter (NeoMet/pH-200L) at room temperature. The viscosity was measured by using the viscometer (Bookfield/RVD-II +P), $10 \mathrm{rpm}$ and spindle no. 4 under room temperature. Color measurement of base serum and sample were performed by using Chroma meter (Konica Minolta) through $L^{*}, a^{*}, b^{*}$ color scale of $\mathrm{CIE}$. The $\mathrm{L}^{*}$ value represents the brightness from black $(0)$ to white $(+100)$, a* value represents from green $(-60)$ to red $(+60)$ while $b^{*}$ value represents from blue $(-60)$ to yellow $(+60)$. The measurements were performed in three replicates.

Table 1. Formulas of base serum and serum containing perilla protein and oil

\begin{tabular}{|c|c|c|c|}
\hline Part & Ingredients & Base Serum & Serum sample \\
\hline \multirow[t]{9}{*}{ A } & Tocopheryl Acetate & 0.10 & 0.10 \\
\hline & Caprylic/Capric Triglyceride & 0.50 & 0.50 \\
\hline & Jojoba Oil & 2.00 & - \\
\hline & Perilla Oil & - & 2.00 \\
\hline & Isopropyl Palmitate & 1.00 & 1.00 \\
\hline & Isopropyl I sostearate & 1.00 & 1.00 \\
\hline & Dimethicone & 1.00 & 1.00 \\
\hline & C12-15 Alkyl Benzoate & 1.00 & 1.00 \\
\hline & PEG-40 Hydrogenated Castor Oil & 0.20 & 0.20 \\
\hline \multirow[t]{4}{*}{ B } & Dl Water & qs to 100 & qs to 100 \\
\hline & Methyl Gluceth-20 and Glycerin & 1.50 & 1.50 \\
\hline & $\begin{array}{l}\text { Sodium Acrylates/Beheneth-25 Methacrylate } \\
\text { Crosspolymer (and) Hydrogenated Polydecene } \\
\text { (and) Lauryl Glucoside } \\
\text { Hydroxyethyl Acrylate/Sodium Acryloyldimethyl } \\
\text { Taurate Copolymer (and) Squalane }\end{array}$ & 1.50 & 1.50 \\
\hline & (and) Polysorbate 60 & 2.50 & 2.50 \\
\hline \multirow[t]{2}{*}{$\mathrm{C}$} & Dl Water & 2.00 & 2.00 \\
\hline & Citric acid & 0.15 & 0.15 \\
\hline \multirow[t]{2}{*}{$\mathrm{D}$} & Perilla Protein & - & 1.00 \\
\hline & DMDM Hydantoin & 1.00 & 1.00 \\
\hline
\end{tabular}




\section{Sensory evaluation}

Sensory satisfaction of the finished products was evaluated by 20 volunteers ( 10 males and 10 females). The different skin feel attributes were selected to properly discriminate the serum on distinct stages of evaluation (Lee et al., 2005). These attributes were spreadability, moisturizing, absorbability, smell, feeling after application and texture and appearance. A 0-6 scale was used where 0 was the less and 6 was the most sensory satisfaction.

\section{Statistical analysis}

All experiments were done in triplicate and all results are presented as mean \pm SD. The statistical analyses of collected datafor protein and oil recovery were performed using SPSS version 19.0 (IBM). One-way analysis of variance (ANOVA) and multiple comparisons by Tukey's were performed to analyze the difference among data. Statistical differences were considered to be significant at $\mathrm{P}<0.05$.

\section{Results and discussion}

\section{Effect of crude extract to $t$-butanol ratio on protein partitioning}

Effect of the crude extract to $t$-butanol ratio on protein partitioning and oil extraction is revealed in Figure 1 . The highest protein recovery $(13.09 \%)$ and oil recovery $(36.63 \%)$ were obtained from the interphase and top phase of the TPP system at 1:2 crude extract: $t$-butanol. The high amount of $t$-butanol makes a flocculate and increase buoyancy and lead protein favor to be extracted in the interphase (Tan et al., 2015). The increasing of $t$-butanol providing a higher oil yield was agreed with the previous study of TPP system (Duttaet et al., 2015). From this result, the ratio of crude extract to $t$-butanol at 1:2 was selected to study the effect of ammonium sulfate concentration on protein partitioning.

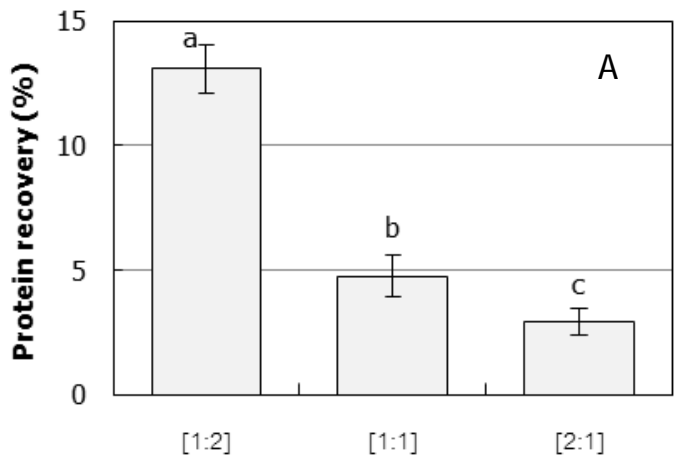

Crude extract : t-butanol ratio

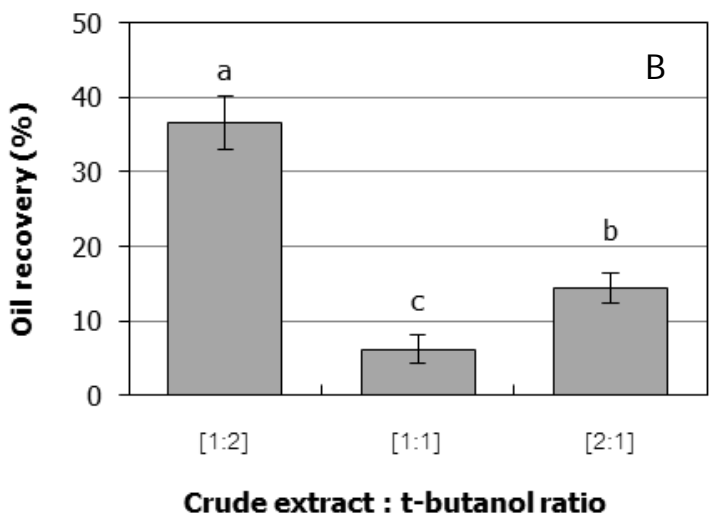

Figure 1. Effect of crude extract to $t$-butanol ratio on protein recovery $(A)$ in the interphase and oil recovery in the top phase $(B)$ of TPP

\section{Effect of ammonium sulfate concentration on protein partitioning}

The study on effect of ammonium sulfate concentration was explored by using the ratio of crude extract to $t$-butanol at 1:2 with varying the concentration of $\left(\mathrm{NH}_{4}\right)_{2} \mathrm{SO}_{4}$ at 20,30 and $40 \%(\mathrm{w} / \mathrm{v})$. As shown in Figure $2 \mathrm{~A}$, the salt concentration of $30 \%$ provided the highest recovery of protein $(13.18 \pm 0.48 \%)$. However, it was not significantly different from that of the $40 \%$ 
$\left(\mathrm{NH}_{4}\right)_{2} \mathrm{SO}_{4}$ which exhibited $13.06 \pm 0.65 \%$ recovery. Increasing the concentration of $\left(\mathrm{NH}_{4}\right)_{2} \mathrm{SO}_{4}$ increased protein amount in the interphase of TPP (Chaiwut et al., 2010). The $40 \%\left(\mathrm{NH}_{4}\right)_{2} \mathrm{SO}_{4}$ giving the maximum protein in the interphase was revealed (Gagaoua et al., 2014). However, it has also been reported that the $30 \%(\mathrm{w} / \mathrm{v})\left(\mathrm{NH}_{4}\right)_{2} \mathrm{SO}_{4}$ was the best concentration for applying to TPP effectively (Rawdkuen et al., 2010). From the Figure 2B, the highest oil recovery $(36.50 \pm 3.48 \%)$ was obtained from top phase at $40 \%\left(\mathrm{NH}_{4}\right)_{2} \mathrm{SO}_{4}$. This value was not significantly different from $35.13 \pm 2.67$ recovery of the $30 \%$ salt. This might be attributed to the highest polarity in the aqueous bottom phase due to high amount of salt rendering the oil to be moved to the top phase.

A

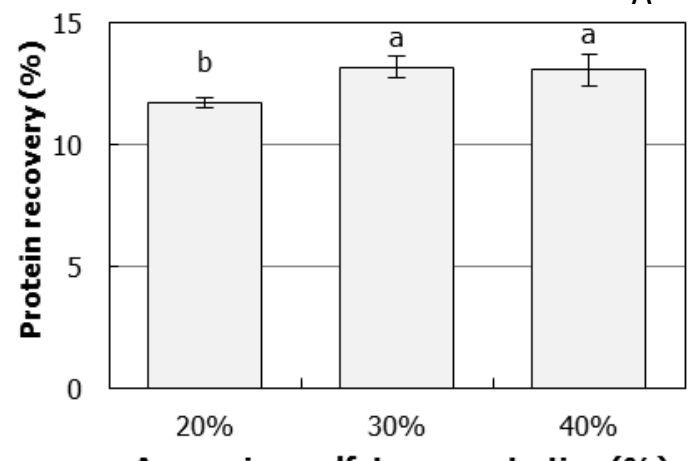

Ammonium sulfate concentration (\%)
B

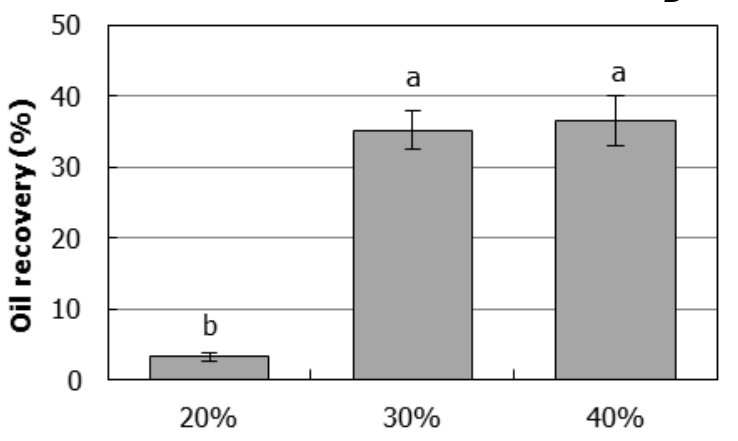

Ammonium sulfate concentration (\%)

Figure 2. Effect of ammonium sulfate concentration on protein recovery in the interphase (A) and oil recovery in the top phase (B) of TPP

\section{GC-MS analysis of fatty acid compositions in perilla oil}

As shown in Table 2, two polyunsaturated fatty acids (PUFA) were identified in the perilla oil. The main PUFA was linolenic acid (18:3) of 70.63\% followed by linoleic acid (18:2). Saturated fatty acids accounted for $16.51 \%$ was belonged to palmitic acid, stearic acid and arachidic acid. High amount of linoleic and linolenic acid were the significant fatty acids in term of quantity and quality of perilla oil (Siriamornpun et al., 2006). The linolenic acid (ALA) content is predominantly about $55-60 \%$ (Siriamornpun et al., 2006). It is noticed that the ALA in this study was higher than all previous reports. Ultrasonic-assisted aqueous enzymatic extraction using response surface provided $31.34 \%$ oil yield containing ALA as major component of $64.05 \%$ (Li et al., 2017). Similarly, soxhlet extraction using hexane as solvent and cold pressing extraction exhibiting $35.20 \%$ and $28.60 \%$, respectively of perilla oil yields gave lower content of ALA at $62.26 \%$ and $60.11 \%$, respectively ( $L i$ et al., 2017). Supercritical fluid extraction of perilla oil using carbondioxide and LPG could extract the linolenic acid as a majority fatty acid of $58.00 \%$ and 57.24\%, respectively (Scapin et al., 2017).

\section{Stability and satisfaction test of serum containing perilla protein and oil}

The facial moisturizing serum was prepared by cold process and mixed using homogenizer. After centrifugation at $6000 \mathrm{rpm}$ for $20 \mathrm{~min}$, phase separations were not observed in both the base and serum containing perilla protein and oil. Then the serums were subjected to acceleration test by heating-cooling cycle. As shown in Table 3, the pH values of 
the base before and after heating and cooling test were 5.50 and 5.61, respectively, while the perilla serum exhibited 5.54 and 5.60 , respectively. The results of $\mathrm{pH}$ values slightly changed indicating their high stability against acceleration test. Determination of the $\mathrm{pH}$ of a formulation intended for cutaneous application is extremely important, since it must be compatible with the $\mathrm{pH}$ of the application site. The serum in this study was designed to have $\mathrm{pH}$ between 5.50-5.60. The natural $\mathrm{pH}$ of the skin comes from the secretions of sweat and sebaceous glands, and lactic acid production, which leads to the formation of a protective film over the entire skin surface, designated hydrolipidic film. The skin normally has an average $\mathrm{pH}$ of 5.5, although this may vary slightly depending on the area of the body (Tichota et al., 2014).

Table 2. Fatty acid composition of perilla oil extracted by the TPP

\begin{tabular}{lc}
\hline \multicolumn{1}{c}{ Fatty acids } & $\%$ Content $(\mathrm{w} / \mathrm{w})$ \\
\hline Saturated fatty acids & \\
Palmitic acid (16:0) & $10.23 \pm 0.56$ \\
Stearic acid (18:0) & $6.07 \pm 0.12$ \\
Arachidic acid (20:0) & $0.21 \pm 0.003$ \\
\hline Unsaturated fatty acids & $11.17 \pm 0.14$ \\
Linoleic acid (18:2) & $70.63 \pm 2.49$ \\
Linolenic acid (18:3) & $1.69 \pm 0.06$ \\
\hline Other volatile components & \\
\hline
\end{tabular}

Table 3. Values of $\mathrm{pH}$, viscosity, and color of serums before and after heating-cooling cycles

\begin{tabular}{llcccc}
\hline \multirow{2}{*}{ Formula } & \multirow{2}{*}{ Unit } & \multicolumn{2}{c}{ Base serum } & \multicolumn{2}{c}{ Perilla serum } \\
\cline { 2 - 6 } & & Before & After & Before & After \\
\hline pH & & $5.50 \pm 0.16$ & $5.61 \pm 0.07$ & $5.54 \pm 0.21$ & $5.60 \pm 0.11$ \\
\hline Viscosity & $\mathbf{C P}$ & $13,553 \pm 233$ & $13,493 \pm 141$ & $12,713 \pm 95$ & $12,540 \pm 103$ \\
\cline { 2 - 6 } Torque & $\%$ & $67.77 \pm 2.16$ & $62.47 \pm 1.14$ & $63.57 \pm 3.86$ & $57.70 \pm 1.95$ \\
\hline Color & $\mathbf{L}$ & $64.70 \pm 0.13$ & $64.42 \pm 0.06$ & $67.77 \pm 0.20$ & $66.87 \pm 0.43$ \\
\cline { 2 - 6 } & $\mathbf{a *}$ & $-0.52 \pm 0.01$ & $-0.68 \pm 0.02$ & $-0.59 \pm 0.04$ & $-0.70 \pm 0.04$ \\
\cline { 2 - 6 } & $\mathbf{b *}$ & $-2.22 \pm 0.06$ & $-2.14 \pm 0.04$ & $-1.60 \pm 0.30$ & $-1.59 \pm 0.24$ \\
\cline { 2 - 6 } & $\mathbf{A E}$ & & $0.33 \pm 0.07$ & $0.91 \pm 0.25$ \\
\hline
\end{tabular}

The viscosities of the base serum before and after heating and cooling test were quite similar (Table 3). This implied the products contained enough stabilizing ingredients and the addition of perilla protein and oil was compatible with other ingredients. Amount of consistency agent was important to keep the viscosity of the formulation constant during the stress conditions applied (Miner, 1993). Presence of nonionic surfactant PEG-40 hydrogenated castor oil in the formula may cause a small reduction in viscosity (Miller \& Loffler, 2006). 
The results of color measurement of the base serum and sample before and after heating-cooling test were aligned in Table 3. The $L^{*}$ means the amount of reflected light, and can range from 0 (black) to $100 \%$ (white); the a* and b* represent, respectively, the colors from green to red or blue to yellow, and the values range from -60 (close to green or blue) to +60 (close to red or yellow). Through the values of $L^{*}, a^{*}$ and $b^{*}$, the overall color change $(\Delta \mathrm{E})$ can be calculated. Minor changes of color in both base and serum were detected after acceleration test to give less $\Delta \mathrm{E}$ of 0.33 and 0.91 , respectively. This color changes were not visible to the naked eye. Thus, it was presumable that there were no changes in the color of the serum containing perilla protein and oil after heating-cooling cylcle. Color stability of the serum might suggest the absence of lipid degradation from oxidation reactions, and revealed lipid stability during thermal process and storage. Oxidative instability is a concern mainly associated with lipids consisting of unsaturated fatty acids (J annin et al., 2008). Lipid oxidation reactions generate colored compounds and thus color change in the formulation can give information about lipid stability (Tichota et al., 2014; Gray, 1978).

The consumer satisfaction to a finish product received the mean value of very good score. Oils and proteins are generally considered as skin moisturizing agents. The oils provide occlusive barrier which prevents water loss from skin layer, on the other hand, the protein absorb water from atmosphere delivering skin moisturization. As shown in Figure 3, the perilla serum exhibited higher sensory satisfaction score than those of the base serum in all attribute tests. Moisturizing and sense of smell attributes of the perila serum possessed the highest satisfaction among the 20 volunteers. From the maximum scale of 6 , they obtained similar mean score of $5.70 \pm 0.46$, while the base serum showed lower satisfying scores of $4.80 \pm 0.46$ and $4.30 \pm 0.85$ for moisturizing and sense of smell, respectively. Spreadability property of perilla serum also showed higher gratifying score of $5.65 \pm 0.48$ when compared to $5.20 \pm 0.61$ of the base formula. The texture and feeling after application were also good satisfied which scored $5.45 \pm 0.50$ and $5.35 \pm 0.74$, respectively. The absorbability was less scored at $4.95 \pm 0.68$ which might be from watery feeling of the product. The serum in this study was designed to have water breaking property during application which might need time for a while to absorb on to skin surface. However, feeling after application was satisfied by the volunteers and obtained high score as described above.

\section{Conclusion}

Protein and oil from perilla seed could be simultaneously extracted by using TPP. The TPP system consisted of the ratio of crude extract to $t$-butanol $1: 2$ and $30 \%(\mathrm{w} / \mathrm{v})\left(\mathrm{NH}_{4}\right)_{2} \mathrm{SO}_{4}$ giving the highest protein recovery (13.18 $3.48 \%)$ and oil recovery $(35.13 \pm 2.67 \%)$. The oil and protein from perilla seed could be incorporated in moisturizing serum formulation providing high stability in $\mathrm{pH}$, viscosity and color. The product also showed good satisfaction from 20 volunteers, especially spreadability, smell, moisturizing, feeling after application and texture properties.

\section{Acknowledgement}

Authors are grateful to Mae Fah Luang University for facility support. 


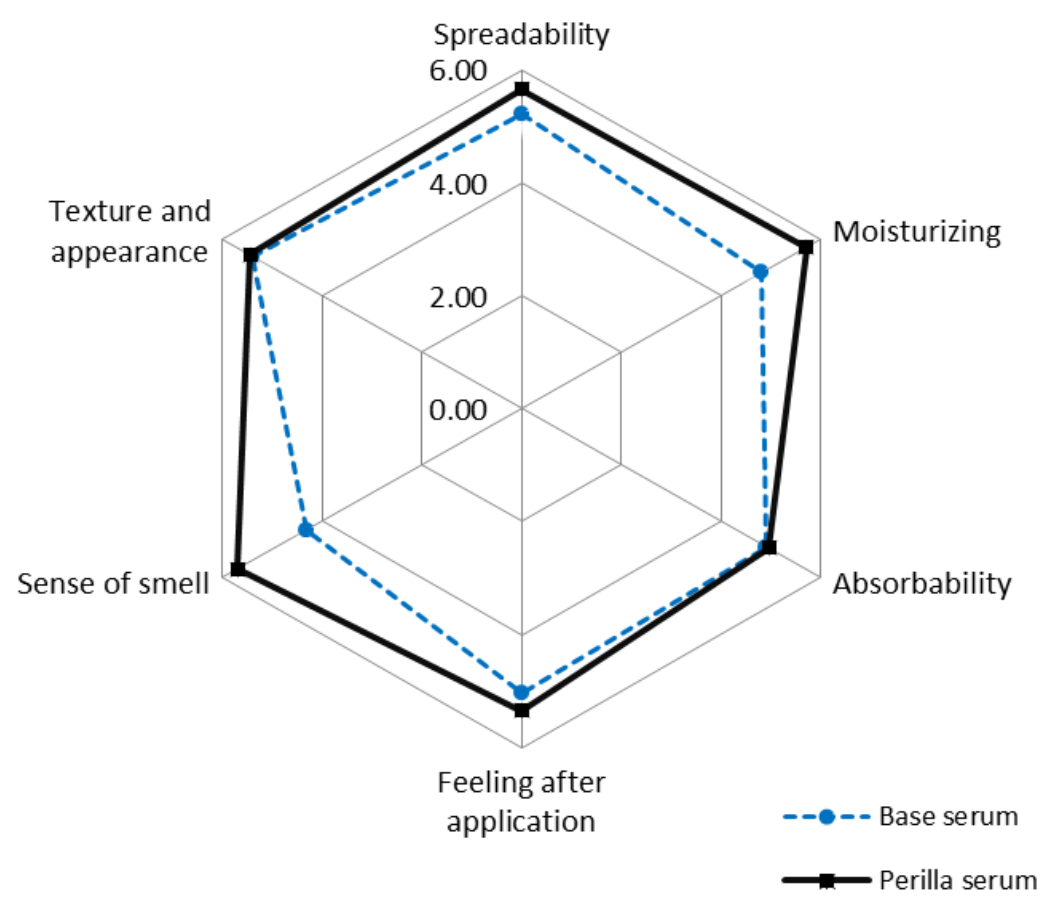

Figure 3. Satisfaction evaluation by 20 volunteers for perilla serum ( $\rightarrow-$ ) compared to base formulation $(\cdots \cdot \cdots)$

\section{References}

Azarkan, M., Moussaoui, A. E., van Wuytswinkel, D., Dehon, G. \& Looze, Y. (2003). Fractionation and purification of the enzymes stored in the latex of Carica papaya. Journal of Chromatography B, 7901-2), 229-238. https://doi.org/10.1016/S15700232(03)00084-9

Bradford, M. M. (1976). A rapid and sensitive method for the quantitation of microgram quantities of protein utilizing the principle of protein-dye binding. Analytical Biochemistry, 72(1-2), 248-254. https://doi.org/10.1016/0003-2697(76)90527-3

Chaiwut, P., Pintathong, P. \& Rawdkuen, S. (2010). Extraction and three-phase partitioning behavior of proteases from papaya peels. Journal of Process biochemistry, 45(7), 11721175. https://doi.org/10.1016/j. procbio.2010.03.019

Chang, H. H., Chen, C. S. \& Lin, J. Y. (2009). Dietary perilla oil lowers serum lipids and ovalbumin-specific IgG1, but increase total IgE levels ovalbumin-challenged mice. Food and Chemical Toxicology, 474), 848-854. https://doi.org/10.1016/j.fct.2009.01.017

Miller, D. \& Löffler, M. (2006). Rheological effects with a hydrophobically modified polymer. Colloids and Surfaces A: Physicochemical and Engineering Aspects, 288(1-3), 165-169. https://doi.org/10.1016/j.colsurfa.2006.04.022 
Dutta, R., Sarkar, U. \& Mukherjee, A. (2015). Process optimization for the extraction of oil from Crotalaria juncea using three phase partitioning. Industrial Crops and Products, 71, 8996. https://doi.org/10.1016/j.indcrop.2015.03.024

Gagaoua, M., Boucherba, N., Darenfed A. B., Ziane, F., Rabah S. N., Hafid, K. \& Boudechicha, H. R. (2014). Three-phase partitioning as an efficient method for the purification and recovery of ficin from Mediterranean fig (Ficus carica L.) latex. Separation and Purification Technology, 132, 461-467. https://doi.org/10.1016/j.seppur.2014.05.050

Gray, J. I. (1978). Measurement of lipid oxidation: a review. Journal of American Oil Chemists' Society, 55(6), 539-546. https://doi.org/10.1007/BF02668066

Honda, G., Koezuka, Y., Kamisako, W. \& Tabata, M. (1986). Isolation of sedative principles from Perilla frutescens. Chemical and Pharmaceutical Bulletin, 34(4), 1672-1677. https://doi.org/10.1248/cpb.34.1672

Jannin, V., Musakhanian, J., \& Marchaud, D. (2008). Approaches for the development of solid and semi-solid lipid-based formulations. Advanced Drug Delivery Reviews, 6a6), 734746. https://doi.org/10.1016/j.addr.2007.09.006

J ung, M., Chung, H., Choi, J., J ung, M. J., Chung, H. Y. \& Choi J. S. (2011). Antioxidant activity of roasted defatted perilla seed. Natural Product Science, 73), 72-75. http://210.101.116.28 /W_files/kiss2/05003398_pv.pdf

Lee, I. S., Yong, H. M., Kim, J. W., Maeng, Y. J., Lee, C. W., Kang, Y. S., Rang, M. J. \& Kim, H. Y. (2005). Terminology development and panel training for sensory evaluation of skin care products including aqua cream. Journal of Sensory Studies, 205), 421-433. https://doi.org/10.1111/j.1745-459X.2005.00037.x

Lee, J. H., Park, K. H., Lee, M. H., Kim, H. T., Seo, W. D. \& Kim, J. Y. (2013). Identification, characterization, and quantification of phenolic compounds in the antioxidant activitycontaining fraction from the seeds of Korean perilla (Perilla frutescens) cultivars. Food Chemistry, 1362), 843-852. https://doi.org/10.1016/j.foodchem.2012.08.057

Li, H., Zhang, Z., He, D., Xia, Y., Liu, Q. \& Li, X. (2017). Ultrasonic-assisted aqueous enzymatic extraction of oil from perilla seeds and determination of its physicochemical properties, fatty acid composition and antioxidant activity. Food Science and Technology, Campinas, 37Suppl. 1), 71-77. http://dx.doi.org/10.1590/1678-457x.29116

Longvah, T. \& Deosthale, Y. G. (1991). Chemical and nutritional studies on Hanshi (Perilla frutescens) a traditional oil seed from Northeast India. Journal of the American Oil Chemists Society, 68(10), 781-784. https://doi.org/10.1007/BF02662172

Makino, T., Furata, Y., Wakushima, H., Fujii, H., Saito, K. \& Kano, Y. (2013). Anti-allergic effect of Perilla frutescens and its active constituents. Phytotherapy Research, 173), 240-243. https://doi.org/10.1002/ptr.1115

Miner, P. E., (1993). Emulsion rheology: creams and lotions. In: D. Laba (Ed.), Rheological Properties of Cosmetic and Toiletries pp. 313-370. New York: Marcel Dekker.

Mohammad, A. \& Atul, K. (2010). Nutritional and functional characterizations of Perilla Frutescens seed oil and evaluation of its effect on gastrointestinal motility. Malaysian Journal of Pharmaceutical Sciences, 8(1), 1-12. 
Narisawa, T., Fukaura, Y., Yazawa, K. \& Ishikawa, C. (1994). Colon cancer prevention with a small amount of dietary perilla oil high in alpha linolenic acid in an animal model. Cancer, 73(8), 2069-2075. https://doi.org/10.1002/1097-0142(19940415)73:8<2069:: AID-CNCR2820730810>3.0.CO;2-1

Oita, S., Kimura, T., Shibuya, Y., Nihei, N. \& Tanahashi, K. (2008). Extraction and digestibility of Perilla frutescens seed proteins. Japan International Reseearch Center for Agricultural Sciences, 42(3), 211-214. https://doi.org/10.6090/jarq.42.211

Peiretti, P. G., Gasco, L., Brugiapaglia, A. \& Gai, F. (2011). Effects of perilla (Perilla frutescens L.) seeds and supplementation on performance, carcass characteristics, meat quality and fatty acid composition of rabbits. Livestock Science, 138(1-3), 118-124. https://doi.org/10.1016/j.livsci.2010.12.007

Povilaitytee, V. \& Venskutonis, P. R. (2000). Antioxidative activity of purple peril (Perilla frutescens L.), moldavian dragonhead (Dracocephalum moldavica L.), and roman chamomile (AnthemisnobilisL.) extracts in rapeseed oil. Journal of the American Oil Chemists Society, 779), 951-956. https://doi.org/10.1007/s11746-000-0150-1

Rachana C. R. \& Lyju, J. V. (2014). Three Phase Partitioning-A Novel Protein Purification Method. International Journal of ChemTech Research, 67), 3467-3472.

Rawdkuen, S., Chaiwut, P., Pintathong, P. \& Benjakul, S. (2010). Three-phase partitioning of protease from Calotropis procera latex. Biochemical Engineering Journal, 5033), 145149. https://doi.org/10.1016/j.bej.2010.04.007

Scapin, G., Abaide, E. R., Martins, R. F., Vendruscolo, R. G., Mazutti, M. A., Wagner, R. \& Rosa, C. S. (2017). Quality of perilla oil (Perilla frutescens) extracted with compressed $\mathrm{CO}_{2}$ and LPG. The Journal of Supercritical Fluids, 130, 176-182. https://doi.org/10.1016/ j.supflu.2017.08.007

Shin, H. S. \& Kim, S. W. (1994). Lipid composition of perilla seed. Journal of the American Oil Chemists' Society, 71(6), 619-622. https://doi.org/10.1007/BF02540589

Shivani, P., Khushbu, P., Faldu, N., Thakkar, V. \& Shubramanian, R. B. (2011). Extraction and analysis of Jatropha curcas L. seed oil. African Journal of Biotechnology, 1a 79), 1821018213. https://doi.org/10.5897/AJ B11. 776

Siriamornpun, S., Li, D., Yang, L., Suttajit, S. \& Suttajit, M. (2006). Variation of lipid and fatty acid compositions in Thai perilla seeds grown at different locations. Songkhlanakarin Journal of Science and Technology, 28(Suppl. 1), 17-21.

Takano, H., Osakabe, N., Sanbongi, C., Yanagisawa, R., Inoue, K., Yasuda, A., Natsume, M., Baba, S., Ichiishi, E. \& Yoshikawa, T. (2004). Extract of Perilla frutescens enriched for rosmarinic acid, a polyphenolic phytochemical, inhibits seasonal allergic rhinoconjunctivitis in humans. Experimental Biology and Medicine, 2293), 247-254. https://doi.org/10.1177/153537020422900305

Tan, Z. J., Wang, C. Y., Yi, Y. J., Wang, H. Y., Tan, S. Y. \& Li, F. F. (2015). Three phase partitioning for simultaneous purification of aloe polysaccharide and protein using a single-step extraction. Process Biochemistry, 503), 482-486. https://doi.org/10.1016/ j.procbio. 2015.01.004 
Terranova, F., Berardesca, E. \& Maibach, H. (2006). Cellulite: nature and aetiopathogenesis. International Journal of Cosmetic Science, 28(3), 157-167. https://doi.org/10.1111/ j.1467-2494.2006.00316.x

Tichota, D. M., Silva, A. C., Lobo, A. M. S. \& Amarai, M. H. (2014). Design, characterization, and clinical evaluation of argan oil nanostructured lipid carriers to improve skin hydration. International Journal of Nanomedicine, 91), 3855-3864. https://doi.org/ 10.2147/IJ N.S64008

Ueda, H., Yamazaki, C. \& Yamazaki, M. (2002). Luteolin as an anti-inflammatory and antiallergic constituent of Perilla frutescens. Biological and Pharmaceutical Bulletin, 25(9), 1197-1202. https://doi.org/10.1248/bpb.25.1197 